Proc. Indian Acad. Sc1. (Chem. Sci.), Vol. 106, No. 2, April 1994, pp. 339-351.

(C) Printed in India.

\title{
$A b$ initio molecular orbital calculations on ion pair-water complexes of metal halides and oxides
}

\author{
P MOHANDAS ${ }^{a}$, SURJIT SINGH*a and J CHANDRASEKHAR ${ }^{b}$ \\ 'Department of Chemistry, Indian Institute of Technology, Madras 600036, India \\ bDepartment of Organic Chemistry, Indian Institute of Science, Bangalore 560012, India
}

\begin{abstract}
A b$ initio MO calculations are performed on a series of ion-molecular and ion pair-molecular complexes of $\mathrm{H}_{2} \mathrm{O}+\mathrm{MX}(\mathrm{MX}=\mathrm{LiF}, \mathrm{LiCl}, \mathrm{NaCl}, \mathrm{BeO}$ and $\mathrm{MgO}$ ) systems. BSSE-corrected stabilization energies, optimized geometrical parameters, internal force constants and harmonic vibrational frequencies have been evaluated for all the structures of interest. The trends observed in the geometrical parameters and other properties calculated for the mono-hydrated contact ion pair complexes parallel those computed for the complexes of the individual ions. The bifurcated structures are found to be saddle points with an imaginary frequency corresponding to the rocking mode of water molecules. The solventshared ion pair complexes have high interaction energies. Trends in the internal force constant and harmonic frequency values are discussed in terms of ion-molecular and ion-pair molecular interactions.
\end{abstract}

Keywords. $A b$ initio MO calculations; hydrogen bonding; force constants; water; metal halides and oxides.

\section{Introduction}

A major part of research in chemistry and biology pertains to and is conducted in liquid solutions involving ionic species. In many of these systems the ions interact with one another as well as with the solvent. Usually these interactions are of prime interest to chemists and biochemists alike. Moreover, the association of oppositely charged ions is an important step in chemical reactions which in many cases have very small barriers and are diffusion controlled. In the field of solvation chemistry, quantum mechanical calculations on solvated ions and ion pairs have proved to be valuable tools for providing complementary data to those obtained in experiments and computer simulations. Besides being a means of deriving force fields, such calculations can provide valuable insight into the energetics and structural details of microscopic subsystems which cannot be experimentally separated.

Because of the importance of water as a solvent a large number of studies on hydrogen bonding and hydration of ions and ion pairs have been reported in the literature (Kress et al 1975; Mulliken and Ermler 1981; Kecki et al 1982; Kleeberg and Luck 1983; Larson and McMahon 1983; Hermansson et al 1984; Marcus 1985; Falk et al 1986; Gao et al 1986, 1991; Latajka and Scheiner 1987; Friedman 1988; Yates et al 1988; Cammi et al 1989; Hashimoto and Iwata 1989; Probst et al 1989; Luu et al 1990; Arbman et al 1992; Benson and Siebert 1992; Caldwell and Kollman

* For correspondence 
1992; Hermansson 1992; Latajka 1992; Probst 1992; Sola et al 1992). Computer simulation studies (Berkowitz et al 1984; Belch et al 1986; Pettitt and Rossky 1986; Dang and Pettitt 1990; Fukushima et al 1991; Ohtaki and Fukushima 1991) as well as X-ray diffraction (Ohtaki and Fukushima 1992) and neutron scattering (Enderby 1985) experiments showed the existence and significance of different types of ion pairs in aqueous solutions. Although there have been several $a b$ initio results at various degrees of sophistication with respect to basis sets and electron correlation on ion hydration (Mulliken and Ermler 1981; Kecki et al 1982; Hermansson et al 1984; Marcus 1985; Falk et al 1986; Gao et al 1986; Latajka and Scheiner 1987; Yates et al 1988; Cammi et al 1989; Hashimoto and Iwata 1989; Probst et al 1989; Arbman et al 1992; Caldwell and Kollman 1992; Latajka 1992; Probst 1992; Sola et al 1992), ab initio studies on ion-pair hydration are rather limited in the literature (Kress et al 1975; Mulliken and Ermler 1981; Marcus 1985; Gao et al 1991). Moreover, in most of the cases reported earlier, the studies have been confined to the geometries and energetics of the complexes whereas it is known that the nature and strength of the hydration is reflected more precisely in the force constants and vibrational frequencies than any other property.

As an extension of our work on molecular interactions (Brakaspathy and Singh 1986; Shivaglal et al 1988; Shivaglal and Singh 1989, 1992; Singh and Knoezinger 1992; Mohandas et al 1993) we report here ab initio MO results on structure, energetics, internal force constants and harmonic vibrational frequencies for a number of complexes of $\mathrm{H}_{2} \mathrm{O}+\mathrm{MX}(\mathrm{MX}=\mathrm{LiF}, \mathrm{LiCl}, \mathrm{NaCl}, \mathrm{BeO}$ and $\mathrm{MgO}$ ) systems. In the case of $\mathrm{LiF}, \mathrm{LiCl}$ and $\mathrm{NaCl}$ several possible geometries corresponding to the monohydrated contact ion pair and solvent-shared ion pair structures have been considered whereas calculations for $\mathrm{BeO}$ and $\mathrm{MgO}$ were confined to the mono-hydrated structures only. Similar calculations have also been carried out for the corresponding hydrated cations and anions in a number of orientations in order to provide a common basis for comparison. Such hydrated ions and ion-pair structures considered are of importance since they are tailored microscopic subsystems of the actual solvation structure of ion pairs in water and also of water adsorbed on the corresponding crystal surfaces (Heidberg and Haser 1990). The calculations also provide interesting insights into the structural and energetic effects resulting from the presence of a counterion on ion molecular interactions.

\section{Computational details}

$A b$ initio molecular orbital calculations were carried out using the Gaussian-86 package (Frisch et al 1984) of computer codes at 3-21G and 6-31G levels. Since the trends in the values of various parameters calculated at these two levels are similar, only the latter qualitatively superior set of values are considered for the discussion. The geometry optimization in each case was carried out using a super-molecular approach where all the geometrical parameters of the complex were allowed to vary within the symmetry point group. The gradient algorithms contained within the program were used for the calculation of internal force constants and vibrational frequencies. Interaction energies were corrected using the Boys-Bernardi (1970) counterpoise scheme. The calculations were performed on VAX/VMS version V5.1 and Siemens 7580-E computer systems. 


\section{Results and discussion}

\subsection{Energetics and geometrical parameters}

The various structures examined are shown in figure 1, along with definitions of the geometrical parameters of interest. The optimized geometrical parameters and BSSE-corrected interaction energies are given in table 1 . The interaction energies of the solvent shared ion pair complexes correspond to the stabilization relative to $\mathrm{M}^{+}$, $\mathrm{X}^{-}$and one $\mathrm{H}_{2} \mathrm{O}$ unit whereas that for the hydrated contact ion pair is relative to $\mathrm{MX}$ and one $\mathrm{H}_{2} \mathrm{O}$ unit.

3.1a Complexes of water with $\mathrm{LiF}, \mathrm{LiCl}$ and $\mathrm{NaCl}$ : The results for the complexes of water with the free ions $\mathrm{M}^{+}$and $\mathrm{X}^{-}$(III, IV and V) are in general accord with

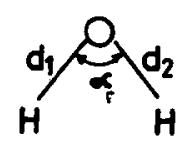

1

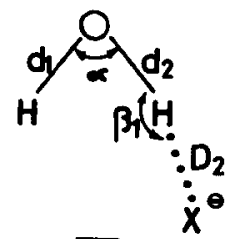

IV

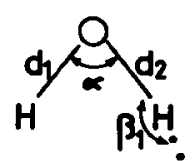

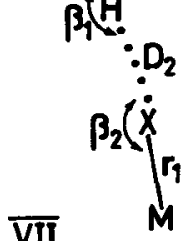
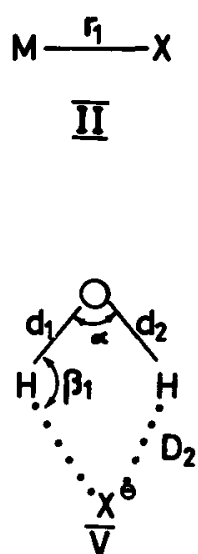

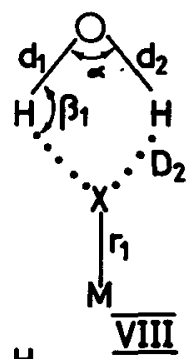

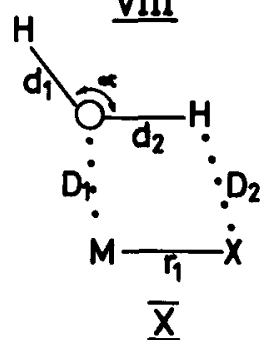

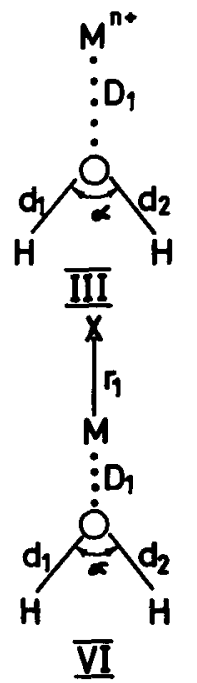

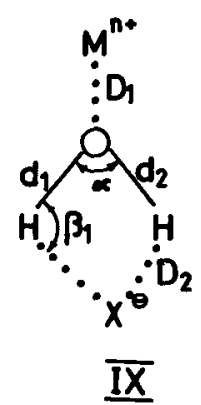

Figure 1. Structural parameters for various complexes of water with $\mathbf{M}^{n+}, \mathbf{X}^{-}$and $\mathbf{M X}$. 


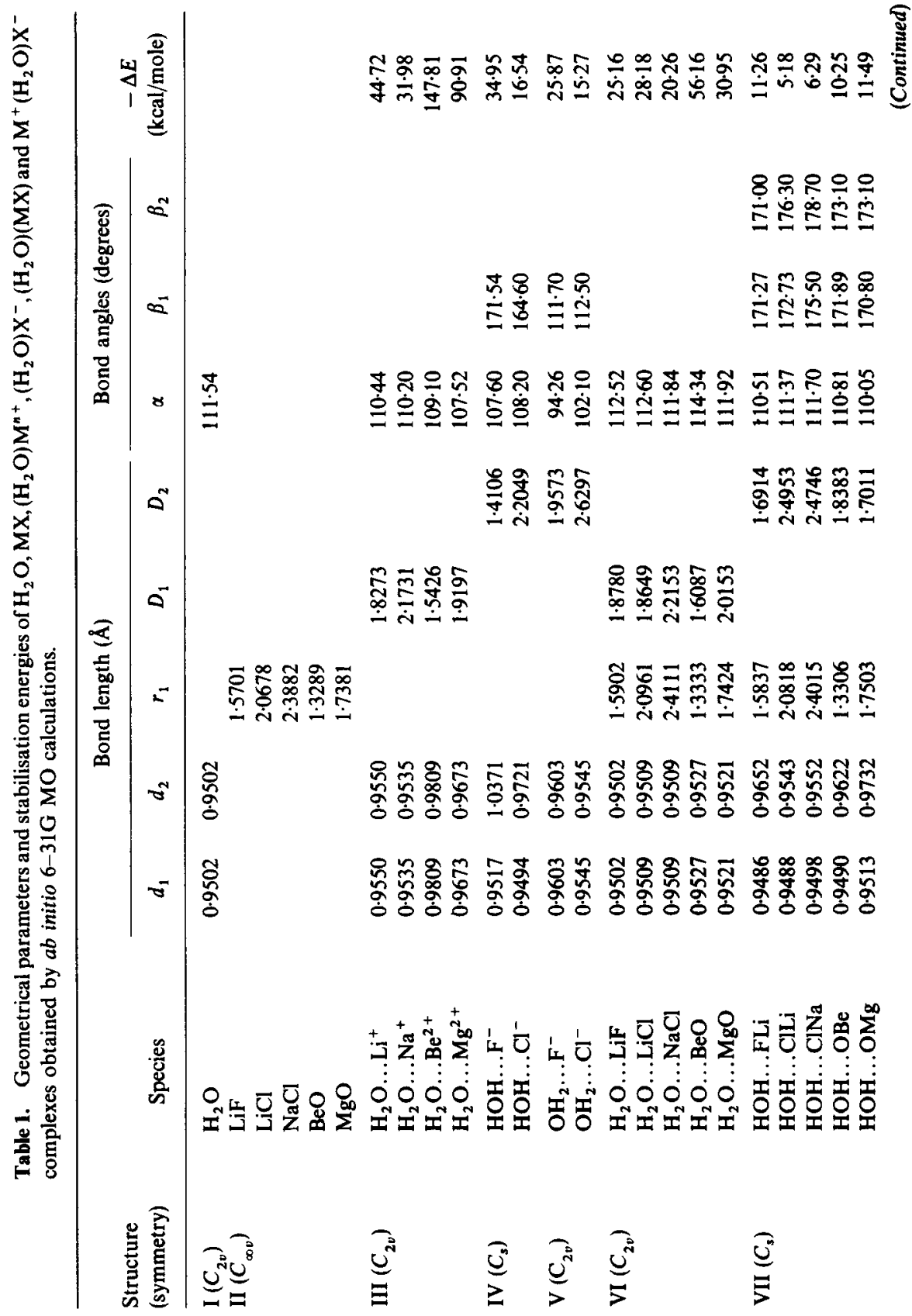




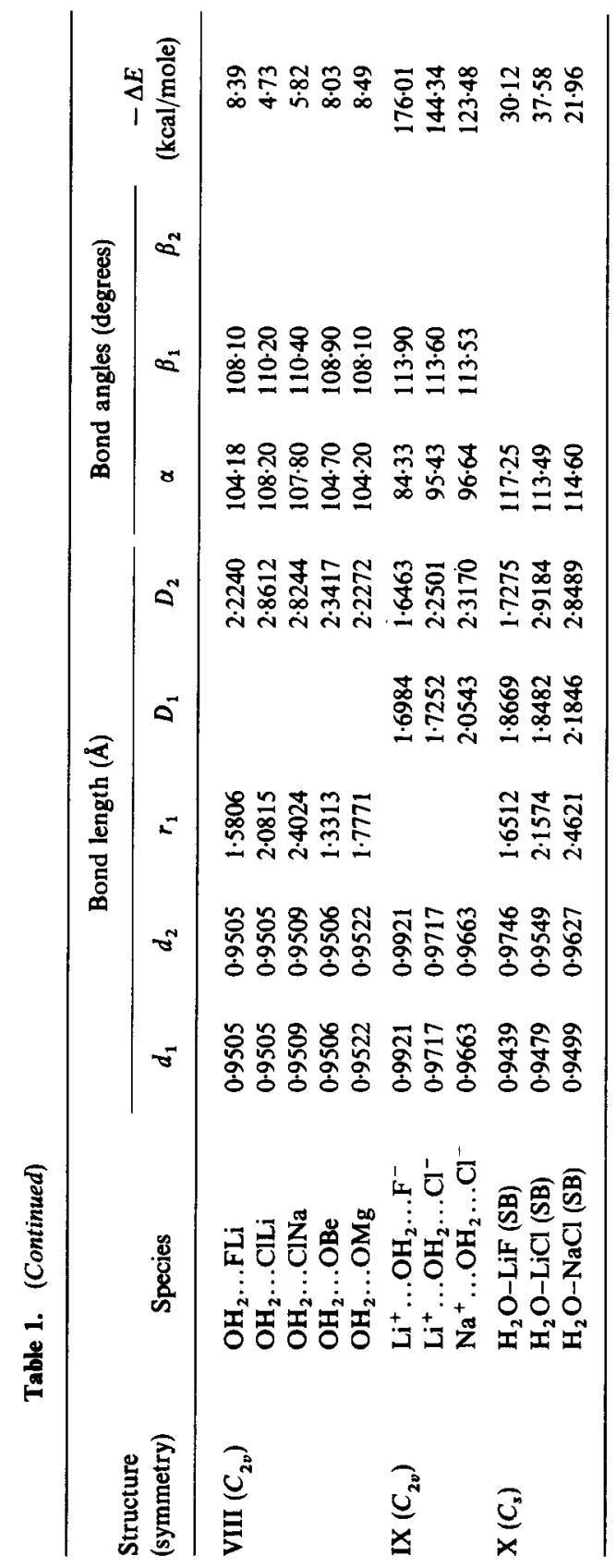


previously established patterns (Kecki et al 1982; Hermansson et al 1984; Falk et al 1986; Gao et al 1986; Latajka and Scheiner 1987; Yates et al 1988; Cammi et al 1989; Latajka 1992). The oxygen lone pair interacts strongly with the cations leading to a $C_{2 v}$ structure, III. Correspondingly, the computed M...O distances are shorter than the values obtained at higher theoretical levels (Hermansson et al 1984; Probst et al 1989; Probst 1992). Interaction of anions with a water molecule leads to minima (IV) where one of the $\mathrm{O}-\mathrm{H}$ units is involved in hydrogen bonding with a slightly nonlinear configuration. The bifurcated structures (V) with two symmetrical hydrogen bonds are higher in energies than the corresponding nonlinear hydrogenbonded structures (IV). The computed stabilization energies are in accord with previous theoretical and experimental values (Latajka 1992), after allowance is made for the differences in internal energy and enthalpy values.

The trends in the results obtained for the mono-hydrated contact ion pairs are parallel to those of the complexes of the individual ions. The interaction energies for these complexes are however lower than those of the respective hydrated ions because the presence of the counter ion markedly reduces the acidic and basic characters, respectively, of $\mathrm{M}^{+}$and $\mathrm{X}^{-}$ions. Thus, coordination through the oxygen of water molecule with the metal end of the ion pair leads to a stable structure (VI) with $C_{2 v}$ symmetry. Hydrogen-bonded structures VII and VIII have lower interaction energies. The bifurcated structures (VIII) are calculated to be less stable than the corresponding mono-hydrogen-bonded strutures (VII). The interaction energy of the $\mathrm{H}_{2} \mathrm{O}$... Li ${ }^{+}$ complex reduces from $44.72 \mathrm{kcal} / \mathrm{mol}$ to 28.18 and $25 \cdot 16 \mathrm{kcal} / \mathrm{mol}$ for $\mathrm{H}_{2} \mathrm{O}$... LiCl and $\mathrm{H}_{2} \mathrm{O}$...LiF complexes, respectively, which shows the effect of the relative basicities of the counter ions on stabilization energies. Similarly, for the hydrogenbonded structures of water with ion pairs (VII and VIII) the interaction energies are much lower than the corresponding water-anion ccomplexes. The interaction energy for $\mathrm{HOH} . . \mathrm{F}^{-}$is reduced from $34.95 \mathrm{kcal} / \mathrm{mol}$ to $11.26 \mathrm{kcal} / \mathrm{mol}$ for $\mathrm{HOH}$...FLi complex. The corresponding reduction in the case of $\mathrm{HOH} . . . \mathrm{Cl}^{-}$is from $16.54 \mathrm{kcal} / \mathrm{mol}$ to 6.29 and $5.18 \mathrm{kcal} / \mathrm{mol}$, respectively, for $\mathrm{NaCl}$ and $\mathrm{LiCl}$ complexes. A similar trend is observed in the case of the bifurcated complexes (VIII) also.

For the solvent-shared ion pairs two possible structures were considered for the optimization. In the $C_{2 v}$ from IX, the $\mathrm{M}^{+}$ions interact with the oxygen atom whereas the $\mathrm{X}^{-}$ion makes a bifurcated hydrogen bond with the $\mathrm{H}_{2} \mathrm{O}$ molecule. The extra source of stabilization in these complexes is provided by the long range electrostatic interaction between the ions. However, these structures are computed to have a Hessian index of 1 , corresponding to saddle points. Another form of solvent-shared ion pair complex can be visualised with a directional hydrogen bond of the $\mathrm{X}^{-}$ion with one of the $\mathrm{O}-\mathrm{H}$ bonds of $\mathrm{H}_{2} \mathrm{O}$. Optimization of such unsymmetrical forms $\left(\mathrm{M}^{+} \ldots \mathrm{H}-\mathrm{O}-\mathrm{H} \ldots \mathrm{X}^{-}\right)$resulted in the formation of another interesting type of structure $X$, called a solvent bound (SB) structure, in which water interacts with the ion pairs in a cyclic arrangement. Incidentally, these structures are found to have the highest stabilization energies among all the mono-hydrated contact ion pairs, even higher than the corresponding $\mathrm{H}_{2} \mathrm{O}$...MX complexes (VI).

The geometrical changes associated with the complexation of water with the contact ion pairs and individual ions follows the pattern of the interaction energies. Consistently, hydrogen bonding lengthens the corresponding $\mathrm{O}-\mathrm{H}$ bond and the elongation depends upon the site of interaction. The increase in the hydrogen bonded $\mathrm{O}-\mathrm{H}$ distance for the water-ion pair complexes follows the order $\mathrm{OH}_{2} \ldots \mathrm{XM}(\mathrm{VIII})<$ 
$\mathrm{H}_{2} \mathrm{O} \ldots \mathrm{MX}(\mathrm{VI})<\mathrm{HOH} \ldots \mathrm{XM}(\mathrm{VII})<\mathrm{H}_{2} \mathrm{O}-\mathrm{MX}(\mathrm{SB})(\mathrm{X})<\mathrm{M}^{+} \ldots \mathrm{OH}_{2} \ldots \mathrm{X}^{-}$(IX). Thus, the maximum change is observed for solvent-shared complexes, IX, which may be attributed to the cooperativity effect due to the presence of the counter ion in a favourable orientation. The non-hydrogen-bonded $\mathrm{O}-\mathrm{H}$ distances $\left(d_{1}\right)$ for the complexes with structures VII and X show a small decrease, the effect being larger in the latter case. The $O \ldots M$ distances $\left(D_{1}\right)$ are greater in the contact ion pair complexes VI, compared to those in the corresponding ion-water complexes III. Similarly, the interaction distances $\left(D_{2}\right)$ in the hydrogen-bonded forms VII and VIII are also higher than those in the structures IV and V. For the solvent-shared ion pair complexes, IX, both the distances $D_{1}$ and $D_{2}$ are found to be shorter than the corresponding values in the ion-water complexes III and V. In all the cases the ion pair distances $\left(r_{1}\right)$ show an increase on complexation with water. All these changes follow the trends in the corresponding interaction energies.

3.1b Complexes of water with $\mathrm{BeO}$ and $\mathrm{MgO}$ : Restuls obtained for mono-hydrated structures of $\mathrm{BeO}$ and $\mathrm{MgO}$ follow the pattern of the corresponding halide structures. Of the three structures considered, two structures, VI and VII, represent minima and the other one (VIII) corresponds to a saddle point as in the case of the halide complexes. Within these three structures the stabilization energies are highest for the structures (VI) and lowest for the bifurcated forms (VIII). Further, the stabilization energies for the complexes, VI, are found to be substantially lower than the corresponding ion-water complexes (III). The geometrical changes associated with the complexation are in accordance with the trends observed in the interaction energies. The elongation of the hydrogen bonded $\mathrm{O}-\mathrm{H}$ distances are in the order $\mathrm{OH}_{2} \ldots \mathrm{OM}$ (VIII) $<\mathrm{H}_{2} \mathrm{O} \ldots$ $\mathrm{MO}$ (VI) $<\mathrm{HOH}$...OM (VII) $<\mathrm{H}_{2} \mathrm{O} \ldots \mathrm{M}^{2+}$ (III). Geometry optimization was also attempted for a solvent-bound type structure which resulted in the breaking of one of the $\mathrm{O}-\mathrm{H}$ bonds of water and the formation of the corresponding hydroxide structures.

\subsection{Internal force constants}

The internal force constants of various complexes considered are provided in table 2 . For the unsymmetrically hydrogen-bonded $\mathrm{O}-\mathrm{H}$ bonds of water molecules, the force constant, $f_{11}$, refers to the force constant of the non-hydrogen bonded and $f_{22}$ for the hydrogen bonded $\mathrm{O}-\mathrm{H}$ bonds.

3.2a Complexes of water with $\mathrm{LiF}, \mathrm{LiCl}$ and $\mathrm{NaCl}$ : Hydrogen bonding reduces the force constant $f_{22}$ of the $\mathrm{O}-\mathrm{H}$ bond, the extent of reduction being a measure of the strength of the hydrogen bond. For the unsymmetrically hydrogen-bonded complexes the $\mathrm{O}-\mathrm{H}$ stretching force constant $f_{11}$ does not show any significant change in its value on complexation except for the solvent-bound complexes where the values are found to increase. In general, the value of the interaction force constant $f_{12}$ becomes less negative on complexation, and even attains positive values in some bifurcated structures as well as in cases where the lone pair of electrons on oxygen atom also interact. The $f_{12}$ values are highest in structures where both the effects are present. The $\mathrm{HOH}$ bonding force constant, $f_{33}$ for the water molecule is found to increase on complexation with cations, anions and ion pairs except for the nonlinear cases (structures IV and VII) where the value is found to decrease slightly. The force 
Table 2. Internal force constants of $\mathrm{H}_{2} \mathrm{O}, \mathrm{MX},\left(\mathrm{H}_{2} \mathrm{O}\right) \mathrm{M}^{n+},\left(\mathrm{H}_{2} \mathrm{O}\right) \mathrm{X}^{-},\left(\mathrm{H}_{2} \mathrm{O}\right)(\mathrm{MX})$ and $\mathrm{M}^{+}\left(\mathrm{H}_{2} \mathrm{O}\right) \mathrm{X}^{-}$complexes obtained by ab initio 6-31G $\mathrm{MO}$ calculations.

\begin{tabular}{|c|c|c|c|c|c|c|c|c|}
\hline \multirow{2}{*}{$\begin{array}{l}\text { Structure } \\
\text { (symmetry) }\end{array}$} & \multirow[b]{2}{*}{ Species } & \multicolumn{7}{|c|}{ Force constants (mdyne/ $\mathbf{\AA}$ ) } \\
\hline & & $f_{11}$ & $f_{22}$ & $f_{12}$ & $f_{33}$ & $f_{\mathrm{MX}}$ & $f_{\mathrm{O} \ldots \mathrm{M}}$ & $f_{\mathrm{H} \ldots \mathrm{x}}$ \\
\hline $\mathrm{I}\left(C_{2 v}\right)$ & $\mathrm{H}_{2} \mathrm{O}$ & $9 \cdot 21$ & $9 \cdot 21$ & $-0 \cdot 14$ & 0.76 & & & \\
\hline II $\left(C_{\infty}\right)$ & $\begin{array}{l}\mathrm{LiF} \\
\mathrm{LiCl} \\
\mathrm{NaCl} \\
\mathrm{BeO} \\
\mathrm{MgO}\end{array}$ & & & & & $\begin{array}{l}3.08 \\
1.47 \\
1 \cdot 14 \\
9.03 \\
3.60\end{array}$ & & \\
\hline III $\left(C_{2 v}\right)$ & $\begin{array}{l}\mathrm{H}_{2} \mathrm{O} \ldots \mathrm{Li}^{+} \\
\mathrm{H}_{2} \mathrm{O} \ldots \mathrm{Na}^{+} \\
\mathrm{H}_{2} \mathrm{O} \ldots \mathrm{Be}^{2+} \\
\mathrm{H}_{2} \mathrm{O} \ldots \mathrm{Mg}^{2+}\end{array}$ & $\begin{array}{l}8.99 \\
9.07 \\
7 \cdot 32 \\
8 \cdot 20\end{array}$ & $\begin{array}{l}8.99 \\
9 \cdot 07 \\
7 \cdot 32 \\
8 \cdot 20\end{array}$ & $\begin{array}{r}-0.04 \\
-0.06 \\
0.08 \\
0.04\end{array}$ & $\begin{array}{l}0.95 \\
0.92 \\
1 \cdot 15 \\
1 \cdot 10\end{array}$ & & $\begin{array}{l}1 \cdot 19 \\
0.75 \\
3 \cdot 60 \\
2 \cdot 08\end{array}$ & \\
\hline IV $\left(C_{s}\right)$ & $\begin{array}{l}\text { HOH...F } \\
\text { HOH....Cl- }\end{array}$ & $\begin{array}{l}8.96 \\
9 \cdot 22\end{array}$ & $\begin{array}{l}5.07 \\
7.87\end{array}$ & $\begin{array}{l}-0.13 \\
-0.12\end{array}$ & $\begin{array}{l}0.56 \\
0.72\end{array}$ & & & $\begin{array}{l}0.97 \\
0.33\end{array}$ \\
\hline $\mathrm{V}\left(\mathrm{C}_{2 v}\right)$ & $\begin{array}{l}\mathrm{OH}_{2} \ldots \mathbf{F}^{-} \\
\mathrm{OH}_{2} \ldots \mathrm{Cl}^{-}\end{array}$ & $\begin{array}{l}8 \cdot 59 \\
8.98\end{array}$ & $\begin{array}{l}8.59 \\
8.98\end{array}$ & $\begin{array}{r}0.12 \\
-0.02\end{array}$ & $\begin{array}{l}0.82 \\
0.88\end{array}$ & & & $\begin{array}{l}0.68 \\
0.30\end{array}$ \\
\hline $\mathrm{VI}\left(C_{2 v}\right)$ & $\begin{array}{l}\mathrm{H}_{2} \mathrm{O} \ldots \mathrm{LiF} \\
\mathrm{H}_{2} \mathrm{O} \ldots \mathrm{LiCl} \\
\mathrm{H}_{2} \mathrm{O} \ldots \mathrm{NaCl} \\
\mathrm{H}_{2} \mathrm{O} \ldots \mathrm{BeO} \\
\mathrm{H}_{2} \mathrm{O} \ldots \mathrm{MgO}\end{array}$ & $\begin{array}{l}9 \cdot 29 \\
9 \cdot 25 \\
9 \cdot 23 \\
9 \cdot 13 \\
9 \cdot 16\end{array}$ & $\begin{array}{l}9 \cdot 29 \\
9 \cdot 25 \\
9 \cdot 23 \\
9 \cdot 13 \\
9 \cdot 16\end{array}$ & $\begin{array}{l}-0.09 \\
-0.08 \\
-0.09 \\
-0.04 \\
-0.06\end{array}$ & $\begin{array}{l}0.85 \\
0.86 \\
0.85 \\
0.94 \\
0.92\end{array}$ & $\begin{array}{l}2 \cdot 75 \\
1.29 \\
1.04 \\
8.63 \\
3.27\end{array}$ & $\begin{array}{l}0.90 \\
0.96 \\
0.62 \\
2.39 \\
1.22\end{array}$ & \\
\hline VII $\left(C_{s}\right)$ & $\begin{array}{l}\text { HOH...FLi } \\
\text { HOH...ClLi } \\
\text { HOH...ClNa } \\
\text { HOH...OBe } \\
\text { HOH...OMg }\end{array}$ & $\begin{array}{l}9 \cdot 26 \\
9 \cdot 28 \\
9 \cdot 21 \\
9 \cdot 24 \\
9 \cdot 09\end{array}$ & $\begin{array}{l}8 \cdot 39 \\
8.99 \\
8.94 \\
8.54 \\
7 \cdot 83\end{array}$ & $\begin{array}{l}-0.12 \\
-0.14 \\
-0.14 \\
-0.13 \\
-0.13\end{array}$ & $\begin{array}{l}0.70 \\
0.74 \\
0.73 \\
0.70 \\
0.68\end{array}$ & $\begin{array}{l}2 \cdot 80 \\
1 \cdot 37 \\
1 \cdot 10 \\
8 \cdot 70 \\
3 \cdot 40\end{array}$ & & $\begin{array}{l}0.32 \\
0.16 \\
0.17 \\
0.28 \\
0.35\end{array}$ \\
\hline VIII $\left(C_{2 v}\right)$ & $\begin{array}{l}\mathrm{OH}_{2} \ldots \mathrm{FLi} \\
\mathrm{OH}_{2} \ldots \mathrm{ClLi} \\
\mathrm{OH}_{2} \ldots \mathrm{ClNa} \\
\mathrm{OH}_{2} \ldots \mathrm{OBe} \\
\mathrm{OH}_{2} \ldots \mathrm{OMg}\end{array}$ & $\begin{array}{l}9 \cdot 29 \\
9 \cdot 24 \\
9 \cdot 22 \\
9 \cdot 27 \\
9 \cdot 13\end{array}$ & $\begin{array}{l}9 \cdot 29 \\
9 \cdot 24 \\
9 \cdot 22 \\
9 \cdot 27 \\
9 \cdot 13\end{array}$ & $\begin{array}{l}-0.06 \\
-0.11 \\
-0.10 \\
-0.07 \\
-0.06\end{array}$ & $\begin{array}{l}0.80 \\
0.81 \\
0.82 \\
0.81 \\
0.79\end{array}$ & $\begin{array}{l}2.85 \\
1.38 \\
1.05 \\
8.64 \\
2.79\end{array}$ & & $\begin{array}{l}0.27 \\
0.13 \\
0.14 \\
0.24 \\
0.27\end{array}$ \\
\hline $\operatorname{IX}\left(C_{2 v}\right)$ & $\begin{array}{l}\mathrm{Li}^{+} \ldots \mathrm{OH}_{2} \ldots \mathrm{F}^{-} \\
\mathrm{Li}^{+} \ldots \mathrm{OH}_{2} \ldots \mathrm{Cl}^{-} \\
\mathrm{Na}^{+} \ldots \mathrm{OH}_{2} \ldots \mathrm{Cl}^{-}\end{array}$ & $\begin{array}{l}6 \cdot 31 \\
7 \cdot 67 \\
8.09\end{array}$ & $\begin{array}{l}6 \cdot 31 \\
7.67 \\
8.09\end{array}$ & $\begin{array}{l}0.60 \\
0.24 \\
0-16\end{array}$ & $\begin{array}{l}0.93 \\
1.01 \\
0.99\end{array}$ & & $\begin{array}{l}2 \cdot 14 \\
1 \cdot 93 \\
1 \cdot 31\end{array}$ & $\begin{array}{l}1.70 \\
0.87 \\
0.72\end{array}$ \\
\hline$X\left(C_{s}\right)$ & $\begin{array}{l}\mathrm{H}_{2} \mathrm{O}-\mathrm{LiF}(\mathrm{SB}) \\
\mathrm{H}_{2} \mathrm{O}-\mathrm{LiCl}(\mathrm{SB}) \\
\mathrm{H}_{2} \mathrm{O}-\mathrm{NaCl}(\mathrm{SB})\end{array}$ & $\begin{array}{l}9 \cdot 78 \\
9 \cdot 43 \\
9 \cdot 29\end{array}$ & $\begin{array}{l}7 \cdot 31 \\
8 \cdot 99 \\
8 \cdot 26\end{array}$ & $\begin{array}{l}-0.10 \\
-0.09 \\
-0.10\end{array}$ & $\begin{array}{l}0.68 \\
0.82 \\
0.74\end{array}$ & $\begin{array}{l}2 \cdot 23 \\
1.07 \\
0.97\end{array}$ & & \\
\hline
\end{tabular}

constant values for the $\mathrm{M}-\mathrm{X}$ bond, $f_{\mathrm{MX}}$ are found to decrease in all the mono-hydrated contact ion pair complexes. The nature and strength of interaction is also reflected in the values of interspecies stretching force constants $f_{\mathbf{O} \ldots \mathrm{M}}$ and $f_{\mathbf{H} \ldots \mathbf{x}}$.

The trends in the force constant values obtained for the complexes of water with the free ions are in general accord with the previously established patterns (Kecki et al 1982; Falk et al 1986; Probst et al 1989; Hermansson 1992; Probst 1992). For all the mono-hydrated cation complexes (structure III) the $\mathrm{O}-\mathrm{H}$ stretching force constant value decreases in accordance with the interaction energies. The variation 
in the values of $f_{12}, f_{33}$ and $f_{\mathrm{O}} \ldots \mathrm{M}$ also follows the same trend. For the mono-hydrated contact ion pair complexes in which the oxygen is coordinated to the metal end of the ion pair (structure VI) the $\mathrm{O}-\mathrm{H}$ stretching force constants show a slight increase. Variation in the values of the force constants $f_{12}, f_{33}$ and $f_{\mathrm{O}} \ldots \mathrm{M}$ are parallel to those for the $\mathrm{H}_{2} \mathrm{O} \ldots \mathrm{M}^{+}$complexes (structure III), the extent of variation being smaller due to the lower acidities of the ion pairs compared to those of the corresponding cations. For the hydrogen-bonded contact ion pair complexes (structure VII) $f_{22}$ values show a decrease compared to the water monomer value as in the case of the HOH... $\mathrm{X}^{-}$ complexes (structure IV). Nevertheless, the variation is due only to a smaller extent to the presence of counter ions. The $\mathrm{O}-\mathrm{H}$ stretching force constant values for the bifurcated hydrogen-bonded complexes (structure VIII) do not show any significant change on complexation. For the solvent-shared ion pair complexes (structure IX) the reduction in the value of the $\mathrm{O}-\mathrm{H}$ stretching force constant is highest among all the structures considered. This may be attributed to the cooperativity effect due to the presence of the counter ion in a favorable orientation. The force constant value is reduced from $9.21 \mathrm{mdyne} / \AA$ for the monomer water molecule to $6.31,7.67$ and 8.09 mdyne/ $\AA$, respectively, for $\mathrm{LiF}, \mathrm{LiCl}$ and $\mathrm{NaCl}$ ion pair complexes. The interaction force constant values $\left(f_{12}\right)$ are increased considerably to $0.60,0.24$ and $0.16 \mathrm{mdyne} / \AA$ respectively from $-0.14 \mathrm{mdyne} / \AA$ for the free water molecule. Variation in the interspecies stretching force constants, $f_{\mathrm{O} \ldots \mathrm{M}}$ and $f_{\mathrm{H} \ldots \mathrm{x}}$ clearly shows the relative acidities and basicities of the corresponding cations and anions. The trends observed in all these force constant values are similar to those observed in the case of interaction energies and geometrical parameters. The case of solvent-bound ion pair complexes (structure $\mathrm{X}$ ) is more interesting. The hydrogen-bonded $\mathrm{O}-\mathrm{H}$ stretching force constant value, $f_{22}$, is decreased in all the three cases, whereas the non-hydrogen-bonded $\mathrm{O}-\mathrm{H}$ stretching force constant value, $f_{11}$, shows a significant increase. The values of $f_{11}$ are $9 \cdot 78,9.43$ and 9.29 mdyne/ $\AA$, respectively, for the complexes of $\mathrm{LiF}, \mathrm{LiCl}$ and $\mathrm{NaCl}$ compared to the water monomer value of $9 \cdot 21 \mathrm{mdyne} / \AA$.

3.2b Complexes of water with $\mathrm{BeO}$ and $\mathrm{MgO}$ : The results obtained for the monohydrated complexes of $\mathrm{BeO}$ and $\mathrm{MgO}$ follow more or less the pattern of the corresponding halide counterparts. For all the three types of complexes considered the hydrogen-bonded $\mathrm{O}-\mathrm{H}$ stretching force constant value decreases compared to the monomer water value. The non-hydrogen-bonded $\mathrm{O}-\mathrm{H}$ stretching force constant for the complexes (structure VII) does not show much variation. For the most stable hydrated complexes of $\mathrm{BeO}$ and $\mathrm{MgO}$ (structure VI) the changes in the values of the force constants, $f_{12}, f_{33}$ and $f_{\mathrm{O} \ldots \mathrm{M}}$ parallel those for the $\mathrm{H}_{2} \mathrm{O} \ldots \mathrm{M}^{2+}$ complexes (structure III), the variation being smaller as in the case of the halide complexes.

\subsection{Harmonic vibrational frequencies}

The harmonic vibrational frequencies of various complexes considered are given in table 3. The calculated uncorrected harmonic frequencies for monomer water molecule are found to be $4137\left(\omega_{3}\right), 3981\left(\omega_{1}\right)$ and $1739\left(\omega_{2}\right) \mathrm{cm}^{-1}$.

3.3a Complexes of water with $\mathrm{LiF}, \mathrm{LiCl}$ and $\mathrm{NaCl}$ : The asymmetric stretching frequency of water molecule $\left(\omega_{3}\right)$ suffers a red shift in all the complexes except for the solvent-bound structures of $\mathrm{LiF}$ and $\mathrm{LiCl}$, whereas the symmetric stretching 
Table 3. Harmonic vibrational frequencies of $\mathrm{H}_{2} \mathrm{O}, \mathrm{MX},\left(\mathrm{H}_{2} \mathrm{O}\right) \mathrm{M}^{n+},\left(\mathrm{H}_{2} \mathrm{O}\right) \mathrm{X}^{-}$, $\left(\mathrm{H}_{2} \mathrm{O}\right)(\mathrm{MX})$ and $\mathrm{M}^{+}\left(\mathrm{H}_{2} \mathrm{O}\right) \mathrm{X}^{-}$complexes obtained by ab initio 6-31G $\mathrm{MO}$ calculations.

\begin{tabular}{|c|c|c|c|c|c|c|c|c|c|}
\hline \multirow{2}{*}{$\begin{array}{l}\text { Structure } \\
\text { (symmetry) }\end{array}$} & \multirow[b]{2}{*}{ Species } & \multicolumn{8}{|c|}{ Frequency $\left(\mathrm{cm}^{-1}\right)$} \\
\hline & & $\omega_{3}$ & $\omega_{1}$ & $\omega_{2}$ & $\mathrm{HOH}_{\text {(roek) }}$ & $H_{\text {oop }}$ & $\omega_{\mathrm{Mx}}$ & $\omega_{\mathrm{o} \ldots M}$ & $\omega_{\mathrm{H} . . . x}$ \\
\hline $\mathrm{I}\left(C_{2 v}\right)$ & $\mathrm{H}_{2} \mathrm{O}$ & 4137 & 3981 & 1739 & & & & & \\
\hline II $\left(C_{\infty v}\right)$ & $\begin{array}{l}\mathrm{LiF} \\
\mathrm{LiCl} \\
\mathrm{NaCl} \\
\mathrm{BeO} \\
\mathrm{MgO}\end{array}$ & & & & & & $\begin{array}{r}1012 \\
654 \\
372 \\
1632 \\
799\end{array}$ & & \\
\hline III $\left(C_{2 v}\right)$ & $\begin{array}{l}\mathrm{H}_{2} \mathrm{O} \ldots \mathrm{Li}^{+} \\
\mathrm{H}_{2} \mathrm{O} \ldots . \mathrm{Na}^{+} \\
\mathrm{H}_{2} \mathrm{O} \ldots \mathrm{Be}^{2+} \\
\mathrm{H}_{2} \mathrm{O} \ldots \mathrm{Mg}^{2+}\end{array}$ & $\begin{array}{l}4061 \\
4084 \\
3635 \\
3856\end{array}$ & $\begin{array}{l}3953 \\
3968 \\
3594 \\
3796\end{array}$ & $\begin{array}{l}1840 \\
1827 \\
1864 \\
1890\end{array}$ & $\begin{array}{l}645 \\
543 \\
988 \\
825\end{array}$ & $\begin{array}{l}697 \\
625 \\
983 \\
935\end{array}$ & & $\begin{array}{r}632 \\
355 \\
1008 \\
585\end{array}$ & \\
\hline $\operatorname{IV}\left(C_{s}\right)$ & $\begin{array}{l}\text { HOH...F } \\
\text { HOH...Cl }\end{array}$ & $\begin{array}{l}4005 \\
4070\end{array}$ & $\begin{array}{l}2473 \\
3680\end{array}$ & $\begin{array}{l}1865 \\
1831\end{array}$ & $\begin{array}{l}564 \\
402\end{array}$ & $\begin{array}{r}1245 \\
818\end{array}$ & & & $\begin{array}{l}408 \\
216\end{array}$ \\
\hline $\mathrm{V}\left(C_{2 v}\right)$ & $\begin{array}{l}\mathrm{OH}_{2} \ldots \mathrm{F}^{-} \\
\mathrm{OH}_{2} \ldots \mathrm{Cl}^{-}\end{array}$ & $\begin{array}{l}3911 \\
4042\end{array}$ & $\begin{array}{l}3943 \\
3975\end{array}$ & $\begin{array}{l}1810 \\
1845\end{array}$ & $\begin{array}{l}581 \mathrm{i} \\
173 \mathrm{i}\end{array}$ & $\begin{array}{r}1040 \\
769\end{array}$ & & & $\begin{array}{l}346 \\
204\end{array}$ \\
\hline $\mathrm{VI}\left(C_{2 D}\right)$ & $\begin{array}{l}\mathrm{H}_{2} \mathrm{O} \ldots \mathrm{LiF} \\
\mathrm{H}_{2} \mathrm{O} \ldots \mathrm{LiCl} \\
\mathrm{H}_{2} \mathrm{O} \ldots \mathrm{NaCl} \\
\mathrm{H}_{2} \mathrm{O} \ldots \mathrm{BeO} \\
\mathrm{H}_{2} \mathrm{O} \ldots \mathrm{MgO}\end{array}$ & $\begin{array}{l}4132 \\
4131 \\
4129 \\
4098 \\
4108\end{array}$ & $\begin{array}{l}4007 \\
3998 \\
3994 \\
3978 \\
3984\end{array}$ & $\begin{array}{l}1782 \\
1787 \\
1785 \\
1818 \\
1811\end{array}$ & $\begin{array}{l}537 \\
562 \\
464 \\
814 \\
609\end{array}$ & $\begin{array}{l}487 \\
515 \\
470 \\
606 \\
602\end{array}$ & $\begin{array}{r}1035 \\
778 \\
414 \\
1700 \\
827\end{array}$ & $\begin{array}{l}350 \\
283 \\
238 \\
583 \\
396\end{array}$ & \\
\hline $\operatorname{VII}\left(C_{s}\right)$ & $\begin{array}{l}\text { HOH...FLi } \\
\text { HOH...ClLi } \\
\text { HOH...ClNa } \\
\text { HOH...OBe } \\
\text { HOH...OMg }\end{array}$ & $\begin{array}{l}4086 \\
4122 \\
4106 \\
4086 \\
4042\end{array}$ & $\begin{array}{l}3763 \\
3957 \\
3937 \\
3813 \\
3564\end{array}$ & $\begin{array}{l}1822 \\
1763 \\
1763 \\
1808 \\
1805\end{array}$ & $\begin{array}{l}440 \\
264 \\
306 \\
421 \\
459\end{array}$ & $\begin{array}{l}820 \\
473 \\
509 \\
755 \\
805\end{array}$ & $\begin{array}{r}965 \\
632 \\
363 \\
1602 \\
807\end{array}$ & & $\begin{array}{l}246 \\
115 \\
119 \\
207 \\
213\end{array}$ \\
\hline VIII $\left(C_{2 v}\right)$ & $\begin{array}{l}\mathrm{OH}_{2} \ldots . \mathrm{FLi} \\
\mathrm{OH}_{2} \ldots \mathrm{ClLi} \\
\mathrm{OH}_{2} \ldots \mathrm{ClNa} \\
\mathrm{OH}_{2} \ldots \mathrm{OBe} \\
\mathrm{OH}_{2} \ldots \mathrm{OMg}\end{array}$ & $\begin{array}{l}4121 \\
4129 \\
4121 \\
4119 \\
4087\end{array}$ & $\begin{array}{l}4029 \\
4001 \\
3999 \\
4022 \\
3995\end{array}$ & $\begin{array}{l}1802 \\
1790 \\
1797 \\
1804 \\
1778\end{array}$ & $\begin{array}{r}364 \mathrm{i} \\
61 \mathrm{i} \\
100 \mathrm{i} \\
316 \mathrm{i} \\
331 \mathrm{i}\end{array}$ & $\begin{array}{l}681 \\
479 \\
526 \\
656 \\
670\end{array}$ & $\begin{array}{r}972 \\
633 \\
363 \\
1594 \\
709\end{array}$ & & $\begin{array}{l}202 \\
129 \\
131 \\
178 \\
193\end{array}$ \\
\hline $\operatorname{IX}\left(C_{2 v}\right)$ & $\begin{array}{l}\mathrm{Li}^{+} \ldots \mathrm{OH}_{2} \ldots \mathrm{F}^{-} \\
\mathrm{Li}^{+} \ldots \mathrm{OH}_{2} \ldots \mathrm{Cl}^{-} \\
\mathrm{Na}^{+} \ldots \mathrm{OH}_{2} \ldots \mathrm{Cl}^{-}\end{array}$ & $\begin{array}{l}3256 \\
3669 \\
3788\end{array}$ & $\begin{array}{l}3583 \\
3755 \\
3832\end{array}$ & $\begin{array}{l}1724 \\
1854 \\
1866\end{array}$ & $\begin{array}{l}833 \mathrm{i} \\
200 \mathrm{i} \\
144 \mathrm{i}\end{array}$ & $\begin{array}{l}1320 \\
1095 \\
1042\end{array}$ & & $\begin{array}{l}899 \\
826 \\
526\end{array}$ & $\begin{array}{l}482 \\
309 \\
227\end{array}$ \\
\hline $\mathrm{X}\left(C_{s}\right)$ & $\begin{array}{l}\mathrm{H}_{2} \mathrm{O}-\mathrm{LiF} \text { (SB) } \\
\mathrm{H}_{2} \mathrm{O}-\mathrm{LiCl}(\mathrm{SB}) \\
\mathrm{H}_{2} \mathrm{O}-\mathrm{NaCl} \text { (SB) }\end{array}$ & $\begin{array}{l}4172 \\
4141 \\
4096\end{array}$ & $\begin{array}{l}3614 \\
3970 \\
3821\end{array}$ & $\begin{array}{l}1696 \\
1772 \\
1760\end{array}$ & $\begin{array}{l}674 \\
432 \\
348\end{array}$ & $\begin{array}{l}860 \\
546 \\
630\end{array}$ & $\begin{array}{l}856 \\
603 \\
307\end{array}$ & & \\
\hline
\end{tabular}

frequency $\left(\omega_{1}\right)$ suffers a blue shift in two cases (structures VI and VIII) and is red-shifted in the rest of the cases. The red shift in the stretching frequency is attributed to the elongation of the $\mathrm{O}-\mathrm{H}$ bond due to the interactions. The blue shift observed in the two cases may be due to an increase in the absolute value of the interaction force constant $f_{12}$. The $\mathrm{HOH}$ bending frequency $\left(\omega_{2}\right)$ is blue-shifted in almost all the cases as expected for hydrogen-bonded systems. The symmetric stretching frequency of water $\left(\omega_{1}\right)$ for the solvent-shared ion pair complexes (structure IX) are found to be higher than the asymmetric stretching frequencies $\left(\omega_{3}\right)$. This is because of the 
change in sign as well as increase in value of the interaction force constant $\left(f_{12}\right)$. The asymmetric stretching frequency of water $\left(\omega_{3}\right)$ for the solvent-bound ion pair complexes of $\mathrm{LiF}$ and $\mathrm{LiCl}$ show a blue shift which is not observed in any other case. This increase in the frequency value is in accordance with the values of the internal force constants $\left(f_{11}\right)$ and $\mathrm{O}-\mathrm{H}$ bond distances $\left(d_{1}\right)$ for these complexes.

The calculated frequency values of the interspecies vibrational modes of all the complexes are within the general range normally expected for hydrogen-bonded complexes (Knoezinger and Schrems 1987). All the frequencies for intermolecular vibrational modes, except for the rocking mode of the water molecule in three cases (structures V, VIII and IX), are found to be real. The observation of imaginary frequency for the rocking mode in these cases shows the transition state nature of these complexes and these represent the reaction coordinates which take these states back to either of the two local minimum configurations involved in such cases. The observation of the imaginary frequency in these systems is similar to the earlier reports (Latajka 1992; Mohandas et al 1993) in the case of water interacting with $\mathrm{F}^{-}, \mathrm{Cl}^{-}$and $\mathrm{CN}^{-}$ions as well as the $\mathrm{LiCN}$ ion pair in the bifurcated configuration. The values of hydrogen out-of-plane bending frequencies $\left(\omega_{o o p}\right)$ and the interspecies stretching frequencies $\left(\omega_{\mathrm{O}} \ldots \mathrm{M}\right.$ and $\left.\omega_{\mathrm{H} . . . \mathrm{X}}\right)$ are direct measures of the strength of the interaction. The out-of-plane bending frequencies are found to be the maximum for solvent-shared ion pair complexes (structure IX), whereas for mono-hydrated contact ion pair complexes (structures VI, VII, VIII and X) $\omega_{o o p}$ values are found to be lower than those for the corresponding ion-water complexes. This clearly shows that in hydrated contact ion pairs the interaction is less pronounced, thus confirming the less acidic or basic nature of the ion pairs compared to those of the individual ions. The comparison of the interspecies stretching frequencies for the two types of complexes also substantiates this fact. The interspecies stretching frequencies are found to be maximum for the solvent shared ion pair complexes (structure IX) in which both $\omega_{\mathrm{O}} \ldots \mathrm{M}$ and $\omega_{\mathbf{H} . . . \mathrm{x}}$ values are higher than those in the corresponding ion-water complexes. This again shows the cooperativity effect due to the presence of a counter ion in a favorable orientation.

3.3b Complexes of water with $\mathrm{BeO}$ and $\mathrm{MgO}$ : The results obtained for the monohydrated complexes of $\mathrm{BeO}$ and $\mathrm{MgO}$ follow the pattern of their $\mathrm{H}_{2} \mathrm{O}+\mathrm{MX}$ counterparts. The symmetric stretching frequency of water $\left(\omega_{1}\right)$ suffers a blue shift in the bifurcated complexes (structure VIII) and is red-shifted in the other two cases (structures VI and VIII), whereas the asymmetric stretching frequency $\left(\omega_{3}\right)$ is redshifted in all the three cases. The $\mathrm{HOH}$ bending frequency $\left(\omega_{2}\right)$ also suffers a blue shift in all the complexes. The observation of an imaginary frequency for the rocking mode of water for the bifurcated complexes (VIII) shows their transition state nature. The magnitude in the frequencies of the interspecies stretching modes show the relative strengths of interaction in these complexes.

\section{Conclusions}

The results obtained for the complexes of water with the individual ions are in general agreement with previously established patterns. The structures and energetics of the mono-hydrated contact ion pairs parallel those for the corresponding ion-water 
complexes. However, the presence of a counter ion reduces the effects to a considerable extent. In the case of the halides, in addition to the three mono-hydrated complexes, solvent-shared and solvent-bound ion pair structures were also considered. The solvent-shared ion pair complexes show high interaction energies and the variation in other properties computed for these complexes are also higher than in any other case. In general, the variations in the values of internal force constants and harmonic vibrational frequencies are consistent with the trends observed in the energetics and structural parameters of the various structures considered. Solvent-bound ion pair complexes are found to have the highest stabilization energies among all the hydrated contact ion pair complexes. These structures are also found to have higher values for the $\mathrm{O}-\mathrm{H}$ internal force constants and frequencies compared to those of the free water molecule. The stabilization of such structures supports the adsorption of water on alkali halide crystal surfaces as well as the possibility of their involvement in the hydration of contact ion pairs. Furthur work in this direction is in progress.

\section{Acknowledgement}

One of us (PM) is thankful to the Council of Scientific and Industrial Research, New Delhi for a fellowship.

\section{References}

Arbman M, Moberg R, Holmberg S, Wahlgren U I and Siegbahn H O G 1992 Int. J. Quantum Chem. 82637

Belch A C, Berkowitz M and McCammon J A 1986 J. Am. Chem. Soc. 1081755

Benson S W and Siebert E D 1992 J. Am. Chem. Soc. 1144269

Berkowitz M, Karim O A, McCammon J A and Rossky P J 1984 Chem. Phys. Lett. 105577

Boys S F and Bernardi F 1970 Mol. Phys. 19553

Brakaspathy R and Singh S 1986 Chem. Phys. Lett. 131394

Caldwell J W and Kollman P A 1992 J. Phys. Chem. 968249

Cammi R, Hans-Jorg Hofmann and Tomasi J 1989 Theor. Chim. Acta 76297

Dang L X and Pettitt B M 1990 J. Phys. Chem. 944303

Enderby J E 1985 Pure Appl. Chem. 571025 (and references therein)

Falk M, Flakus H T and Boyd R J 1986 Spectrochim. Acta A42 175

Friedman H L 1988 Faraday Discuss. Chem. Soc. 851 (and references therein)

Frisch M J, Binkley J S, Schlegel H B, Raghavachari K, Mellius C F, Martin J L, Stewart J J P, Bobrowicz F W, Rohlfing C M, Kahn L R, DeFrees D J, Seeger P, Whiteside R A, Fox D J, Fluder E M and Pople J A 1984 Gaussian 86 (Pittsburgh, PA: Carnegie-Mellon Quantum Publishing Unit)

Fukushima N, Tamura Y and Ohtaki H 1991 Z. Naturforsch. A46 193

Gao J, Boudon S and Wipff G $1991 \mathrm{~J}$. Am. Chem. Soc. 1139610 (and references therein)

Gao J, Garner D S and Jorgensen W L 1986 J. Am. Chem. Soc. 1084784

Hashimoto K and Iwata S 1989 J. Phys. Chem. 932165

Heidberg J and Haser W 1990 J. Electron. Spectrosc. Relat. Phenom. 54971 (and references therein)

Hermansson K 1992 Chem. Phys. 15967

Hermansson K, Olovsson I and Lunell S 1984 Theor. Chim. Acta 64265

Kecki Z, Sadlej J and Sadlej A J 1982 J. Mol. Struct. 8871

Kleeberg H and Luck W A P 1983 J. Solution Chem. 12369

Knoezinger E and Schrems O 1987 Vibrational spectra and structure (ed.) J R Durig (Amsterdam: Elsevier) vol. 16

Kress J W, Clementi E, Kozak J J and Schwartz E 1975 J. Chem. Phys. 633907

Larson J W and McMahon T B 1983 J. Am. Chem. Soc. 1052944 
Latajka Z 1992 J. Mol. Struct. (Theochem) 253225 (and references therein)

Latajka Z and Scheiner S 1987 J. Chem. Phys. 871194

Luu D V, Cambon L and Mathlouthi M 1990 J. Mol. Struct. 237411

Marcus Y 1985 Ion solvation (Chichester, NY: John Wiley)

Mohandas P, Shivaglal M C, Singh S and Chandrașekhar J $1993 \mathrm{~J}$. Mol. Struct. (Theochem) (in press)

Mulliken R S and Ermler W C 1981 Polyatomic molecules: Results of ab initio calculations (New York: Academic Press)

Ohtaki H and Fukushima N 1991 Pure. Appl. Chem. 631743

Ohtaki H and Fukushima N 1992 J. Solution Chem. 2123 (and references therein)

Pettitt B M and Rossky P J 1986 J. Chem. Phys. 845836

Probst M M 1992 J. Mol. Struct. (Theochem) 253275

Probst M M, Spohr E and Heinzinger K 1989 Chem. Phys. Lett. 161405

Shivaglal M C, Brakaspathy R and Singh S 1988 Proc. Indian Acad. Sci. (Chem. Sci.) 100413

Shivaglal M C and Singh S 1989 Int. J. Quantum Chem. 36105

Shivaglal M C and Singh S 1992 Int. J. Quantum. Chem. 44679

Singh S and Knoezinger E 1992 Spectrochim. Acta A48 1767

Sola M, Lledos A, Duran M and Bertran J 1992 Theor. Chim. Acta 81303

Yates B F, Schaefer III H F, Lee T J and Rice J E 1988 J. Am. Chem. Soc. 1106327 